\title{
Visual Pawukon on Decorative Lighting
}

\author{
Anung B. Studyanto ${ }^{1}$, Setyawan ${ }^{2}$, Rahmanu Widayat ${ }^{3}$ \\ \{anungbs@staff.uns.ac.id ${ }^{1}$, setyawan@staff.uns.ac.id ${ }^{2}$,rahmanuwidayat@staff.uns.ac.id ${ }^{3}$ \} \\ ${ }^{1}$ Department of Interior Design, Faculty of Arts and Design, Universitas Sebelas Maret, Indonesia \\ ${ }^{2}$ Department of Crafts/Textile, Faculty of Arts and Design, Universitas Sebelas Maret, Indonesia \\ ${ }^{3}$ Department of Interior Design, Faculty of Arts and Design, Universitas Sebelas Maret, Indonesia
}

\begin{abstract}
The study of Pawukon figures in arts and design has become prominent, considering that these traditional arts have not attracted many followers in the academic milieu. Pawukon figures are similar to zodiacal astrology figures of Westerners. Both predictions also have beautiful pictures as symbols of the wuku characters or zodiac of human beings. Pawukon figures visually contain an aesthetic value. Visual Pawukon Exploration research for decorative lighting design development as an interior aesthetic element explores the visual Pawukon to be applied to decorative lighting designs. The research method used is qualitative in the form of action research, by creating a decorative lighting design development can be used to mark events in a new way. Implementation in Surakarta, from March to November 2020. This product to preserve traditional artworks. It is also expected to become a model for the development of decorative lighting that combines traditions and the creativity of the modern era.
\end{abstract}

Keywords: decorative lighting, design development, pawukon

\section{Introduction}

Pawukon is a prediction about the calculation of time found in primbon books that are owned by all circles, the general public and within the palace. [1] According Sindhunata, that pawukon form of speech implies, is used as the calculation of the good and bad days, to examine the nature of a person's character, to the profit and loss calculation.[2] Hereinafter described, to the current urban communities are not many who know pawukon. but for rural communities is estimated to still believe and use pawukon as determining the implementation of crop farming, celebration and others. In its course, Pawukon was initially only pronounced, then supplemented with text, and in the end, visual Pawukon appeared following the existing Wayang Purwo characters. Another aspect that interested both the writer and the painter remained unknown. [3] There have been many studies on Pawukon; however, very few studies on visual Pawukon development. This motive attracts researchers' attention to exploring the visual Pawukon on decorative lighting. Article Dick van der Meij 'Gods, birds, and trees Variation in Javanese pawukon illustrated manuscripts' to offer beginning to study this illustration by offering an illustrative example and connections that may exist between the maker of illustrated manuscripts.[4] The article by Rahmanu Widayat expresses interest because the characters in Pawukon have elements of wangun, visual arrangement of wangun, placement of wangun and development of Pawukon characters which are related to the concept of wangun and ora wangun [aeng]. [5] As stated by Rahmanu widayat, visual Pawukon is more comfortable for the Javanese (kejawèn) to remember because it appears to 
be like wayang purwa, which is close to life. Spiritually, it means that there is a counterpart between human being's works and gods. The philosophical meaning in the visual pawukon is related to Javanese's life teachings, which need to act carefully to survive, as negligence brings disaster. [5]

Pawukon, outside of belief, has a beauty value that has been passed down from the Javanese ancestors. Pawukon has been developing in Java Island for a long time. According to Prof. Dr. Philip Van Akkeren, a researcher from the Netherlands, Pawukon tracks can be traced since the 10th century, written on the charter of stone and brass or bronze with ancient Javanese letters. The charter reports the use of Javanese habitat structures in the form of a Javanese sign and Pawukon alongside India's calendar. At that time, Pawukon was already used for existing kingdoms, and even rural communities in Java had done it long before. [2]

Efforts to preserve traditional arts, in this case, Pawukon, need to be done given the meaning and role it contains. By developing decorative lighting designs, exploring visual Pawukon is expected to become a model in development and preservation. The aim of the research is to introduce Pawukon to the general public as a cultural heritage product that can function as a marker of events or dates. Next, visual exploration of visual Pawukon through decorative lighting as an effort to preserve traditional arts

\section{Method}

The research method used is qualitative research in the form of action research by creating the development of decorative lighting designs. The research was conducted from March to November 2020 in Surakarta, the use of digital media in the form of computers and cameras was used to support this research process. The technique of learning data is through tracing the pawukon visual library available at Primbon Pawukon, for data learning instruments through interviews and interviews of Damar Kurung lamp makers and observers in Gresik, and observing documentation of its development. The main data is in the form of 30 visual pawukon, which is then re-drawn. Its implementation used a design method through three main processes: exploration process, extraction process, and termination point process. The three stages of the design process are described in four operational steps: 1) the design analysis process and planning targets' determination, namely redrawing the appearance of the pawukon to know and understand the visual characters of the $30 w u k u$. 2). Design analysis process and drafting of design concepts. This is done to get the pawukon visual components and the technique of placing visual Pawukon form on decorative lights. Pawukon can provide time or date information, this is a design concept.3) concept description process and design creation (visualization). with the application of visual pawukon to decorative lamps and the manufacture of Lampu Kurung Pawukon. By developing the design through the transformation process of visual Pawukon, it is expected that new nuances will appear and more appropriate when applied to decorative lighting.

\section{Results and Discussion}

The first study carried out was to redraw Pawukon figures. The Pawukon figures were processed from R.M. Soelardi's drawings who was actively involved in drawing wayang from 
1930-1960 and are available in the book Pawukon 3000. [2] Thirty (30) Pawukon figures include wuku:
1. Shinta
11. Galungan
21. Maktal
2. Landep
12. Kuningan
22. Wuye
3. Wukir
13. Langkir
23. Manahil
4. Kurantil
14. Mandasia
24. Prangbakat
5. Tolu
15. Julungpujud
25. Bala
6. Gumbreg
16. Pahang
7. Warigalit
17. Kuruwelut
26. Wugu
8. Warigagung
18. Marakeh
27. Wayang
9. Julungwangi
19. Tambir
28. Kulawu
10. Sungsang
20. Madangkungan
29. Dukut
30. Watugunung

The redrawing process was conducted by tracing the outline of Pawukon figures. Through redrawing, the digital data of Pawukon figures would be obtained. The Adobe Photoshop program was utilized in the redrawing process. For each Pawukon figure, the standard was meticulously retrieved. The digital results of Pawukon figures are the principals for design development, especially in the application of the Pawukon figures to decorative lighting. Some of the redrawing of Visual Pawukon is presented below.

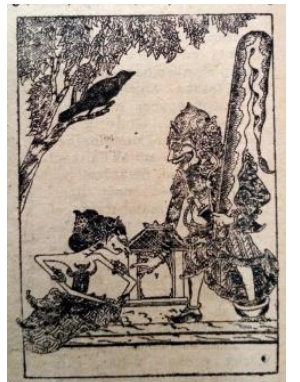

Fig. 1 Wuku Kurantil [6]

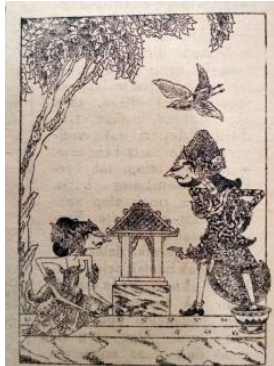

Fig. 3 Wuku Landhep [6]

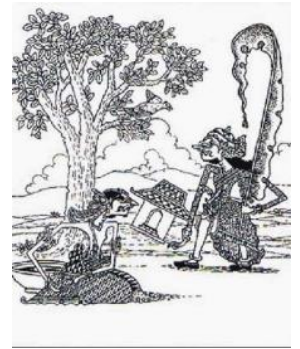

Fig. 2 Redrawing of Wuku Shinta

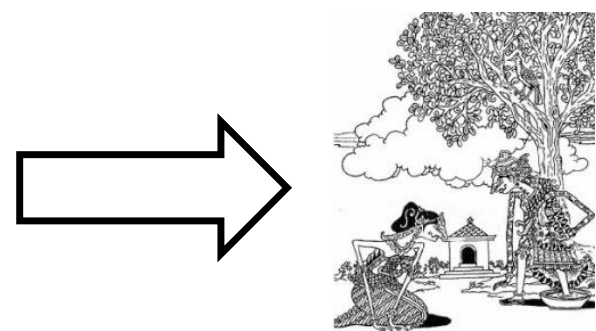

Fig. 4 Redrawing of Wuku Landhep 


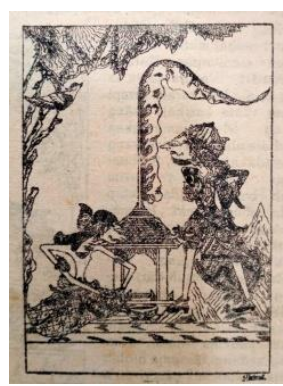

Fig. 5 Wuku Wukir [6]

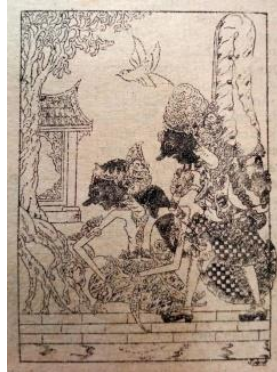

Fig. 7 Wuku Tolu [6]

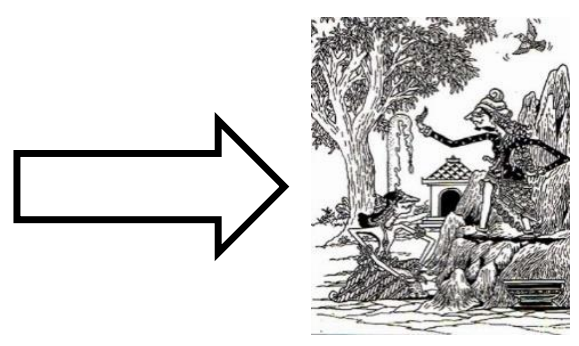

Fig. 6 Redrawing of Wuku Wukir
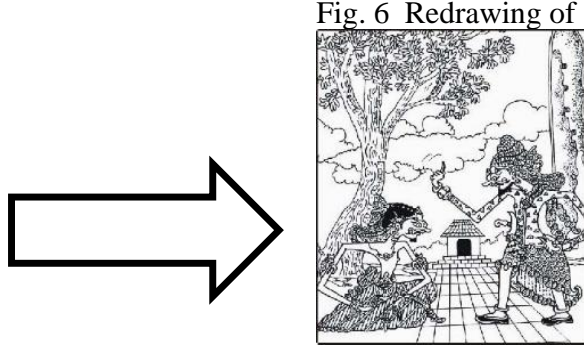

Fig. 8 Redrawing of Wuku Tholu

The second process, by analyzing the design and preparation of the design concept. Pawukon visual components are applied to decorative lamps, paying attention to the technique of placing the visual Pawukon on decorative lamps and the materials used. The Pawukon visual application was made on a wood-based pendant lamp with the printing technique on art paper. Visual Pawukon was placed in the middle of the light area, on its four sides. Two sides were drawn with Visual Pawukon, and the other two sides described Wuku. Effectiveness and efficiency become significant considerations in the use of paper materials and flexibility in exploring visual Pawukon [1].

The concept of wangun (aesthetic) is used in exploring Pawukon figures on decorative lighting, as expressed by Rahmanu Widayat, which is without changing the "inner structure." Furthermore, it is explained that the characters' visuals remain unchanged, as well as the arrangement of the composition of the characters, face to face and not back to back. [5] It is according to the researchers' efforts to redraw the visual Pawukon.

The exploration of visual Pawukon on decorative lighting is also an effort to enrich the visual Pawukon that existed before but with more various media. Based on Dick van der Meij, there are differences in the elements of the Pawukon illustration so that there is no standard in the visual depiction of Pawukon, indicating there is no rigidness. Variations indicate differences in the individual, regional, social, and temporal backgrounds of the creators. [4]

The third process is the application of visual Pawukon to decorative lamps and the manufacture of Lampu Kurung Pawukon. One of the efforts to develop decorative lighting designs with visual Pawukon exploration was inspired by Damar Kurung, developed in Gresik. Pawukon figures were applied to Lampu Kurung (cage lamp), printed in one color. It was intentionally done to see the aesthetic power of the Pawukon figures. The design and product of the lampu kurung Wuku, besides decorative lighting, can also be used as an event marker, among others; the Covid-19 pandemic, 44th UNS Anniversary 75th Indonesian Independence Day. 


\subsection{Lampu Kurung Wuku Covid 19}

Pawukon contains predictions about time calculation. When the World Health Organization (WHO) pronounced Covid-19 as the official name for Coronavirus that was first identified in China on December 31, 2019, there were exciting matters that could be attributed to Wuku in Pawukon. Judging from the date of emergence, the Covid-19 is classified as Wuku Kurantil. The depiction of Wuku Kurantil is described as follows: [7]

- Kuranthil (left) faces Batara Langsur carrying banners.

- The building collapses at the front.

- The Slindhitan bird perches on rengas tree, which shelters it often encounters trouble.

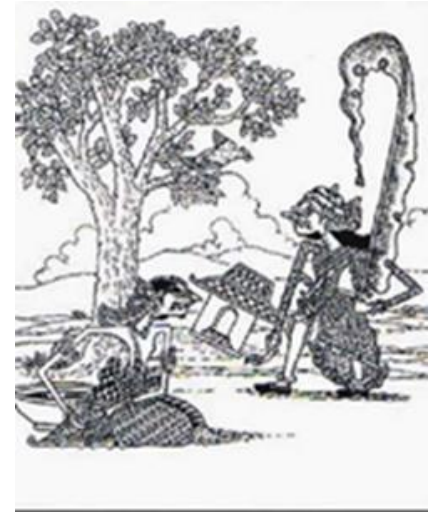

Fig. 9 Redrawing of $W u k u$ Kurantil
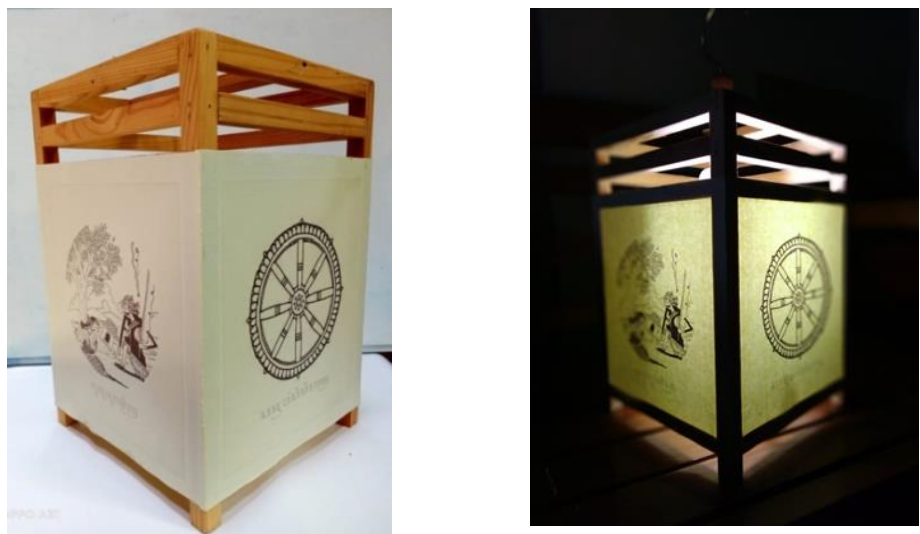

Fig. 10, 11 Visual Application on Wuku Kurantil and Cakra Manggilingan on Decorative Lighting [Lampu Kurung Wuku Covid-19]

Visual Wuku Kurantil is applied to the Covid-19 cage lamp's design by complementing Cakra Manggilingan's visual. The importance of Cakra Manggilingan is about time. The changes that occur have become human nature, from day to day, month to month, and year to year. The conception of time plays an important role. The Javanese community has their calendar system. The composition of these various elements makes for an exciting, comprehensive form.

Wuku Kurantil is advantageous for finding partners but not for marriage or assembling people. The prediction from Wuku Kurantil is in line with the current situation, in which the Covid-19 pandemic has affected all parts of the world. All human beings need to introspect by refraining themselves from staying at home, not doing any activities that invite crowds, and Kurantil resembles a Dhandhang bird (crow) dying of hunger and difficulty striving.

\subsection{Lampu Kurung Wuku Dies Natalis UNS}

Universitas Sebelas Maret Surakarta, often abbreviated as UNS, is one of the public universities located in Surakarta, Central Java. It was officially established on March 11, 1976, marked by a ceremony at the Siti Hinggil Keraton Kasunanan Surakarta. It was also marked by the Presidential Decree of the Republic of Indonesia's announcement on the opening of "Universitas Negeri Surakarta Sebelas Maret. " The origin of UNS itself can be retrieved back to the 1950s. [8] 
Given the establishment date of UNS, March 11, 1976, it is included in Wuku Kulawu. The name works Kulawu is taken from the son number twenty-six of Prabu Watugunung and Dewi Sinta. Raden Kulawu had a twin brother, Raden Wayang. Wuku Kulawu depiction according to Javanese primbon (horoscope) is as follows: [7]

- Batara Sadana; brave, firm stance

- The picture of Gedong at the front; abundant luck he has

- The weapon behind; an honest and straightforward character

- The tree is the Tal Tree [Palmyra Tree]; long life, strong

- The bird is a parrot.

Wuku Kulawu's characteristic is in line with the spirit of UNS. It is expected that this institution provides many benefits to the community, has achievements, is a firm stance, and can fulfill the dream to become a World Class University.

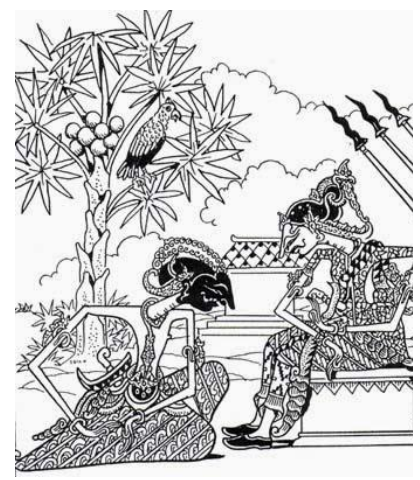

Fig. 12 Redrawing of $W u k u$ Kulawu
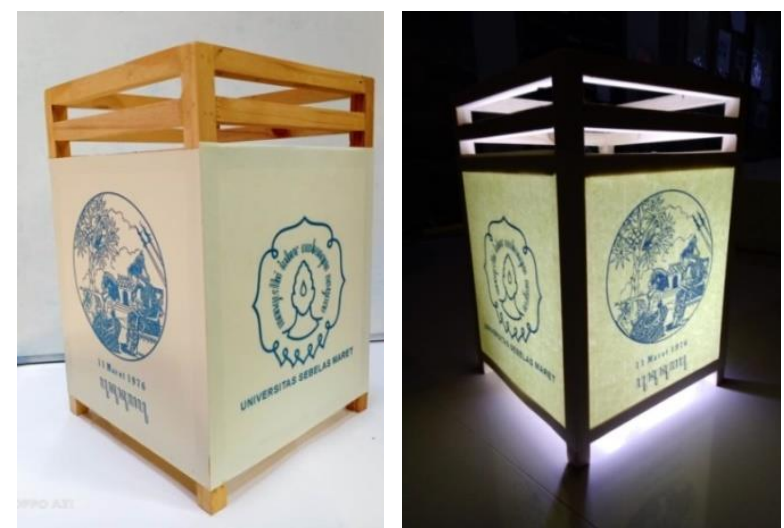

Fig. 13, 14 The Visual Application of Wuku Kulawu and UNS Logo on Decorative Lighting [Lampu Kurung Dies Natalis UNS]

\subsection{Lampu Kurung Wuku HUT RI 17 Agustus}

Visual Pawukon exploration was also applied to the commemoration of the Indonesian Independence Day in a residential area. On the four sides of the cage lamp of the Indonesian Independence Day, there was a visual exploration of Wuku Manahil [August 17, 1945], UNS Logo, Wuku, and the 75th Year Indonesian Independence Logo.

Wuku Manahil takes after the name of son number twenty-one of Prabu Watugunung and Dewi Sinta. Raden Manahil had a twin, Raden Prangbakat. Those who take after wuku Manahil will generally have a character described as follows. The characters and attitude of Wuku Manahil, according to the Javanese primbon, are as follows [7]:

- $\quad$ Batara Citragotra; easy to mingle, cautious, and sharp-minded

- $\quad$ Tigaron tree or wood; firm stance

- $\quad$ Sepahan (minivet) bird; quick-witted and small eater

- $\quad$ The disaster of getting stabbed by a sharp weapon

Given the characters of Wuku Manahil, it is according to Indonesia's conditions during independence, as a nation that had long been struggling to become an independent, strong nation, in a time full of concern.

Wuku Warigalit takes after the name of son number five of Prabu Watugunung and Dewi Sinta. However, according to the gestational age of Dewi Sinta, Warigalit was born from the 
third pregnancy. Of 27 sons of Dewi Sinta, 13 were born twins, while the 14th pregnancy was a singleton. During her first pregnancy, Dewi Sinta gave birth to twins, Raden Wukir and Raden Kurantil. In her second pregnancy, Raden Tolu and Raden Gumbreg were born. Meanwhile, during the third pregnancy, Raden Warigalit and Warigagung were born. Wuku Warigalit descriptions are as follows: [7]

- Warigalit (left) faces Batara Asmara

- Kapodang (black-naped oriole) birds fly over the sulastri (soulattri) tree, and they do not like to mingle with others.

- $\quad$ The temple at the front; pleased to meditate and easily concerned

- Sulastri (soulattri) tree or wood; beautiful, adored by many people

The characters of Wuku Warigalit appear to share similarities with the current condition during the Covid-19 Pandemic. Human beings on earth in general and Indonesia, in particular, require a lot of attention and prayer.

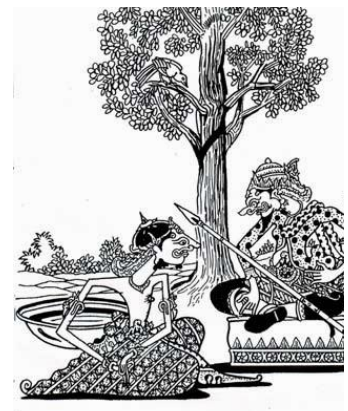

Fig. 15 Redrawing of Wuku Warigalit

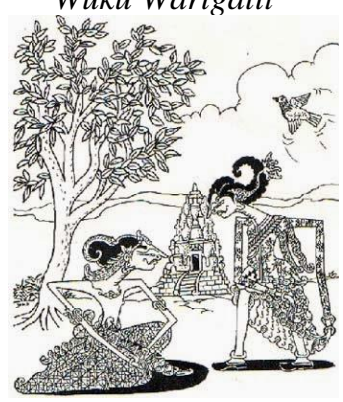

Fig. 16 Redrawing of Wuku Manahil
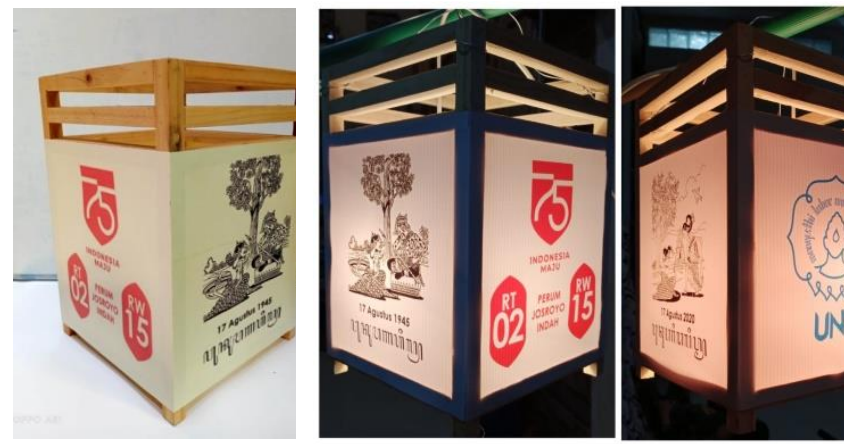

Fig. 17, 18, 19 The Visual Application of Wuku Warigalit, wuku Manahil, $75^{\text {th }}$ Indonesian Independence Day Logo and UNS Logo on Decorative lighting [Lampu Kurung Wuku Indonesian Independence Day]

\section{Conclusions}

Visual Pawukon on decorative lighting as a calendar can be used to mark events in a new way. Decorative lighting with visual Pawukon is an effective medium for preserving traditional arts and has the potential as a creative product variant that can be developed further. 
There is an opportunity for further exploration in the development of decorative lighting designs with the application of visual Pawukon, considering that there are many decorative lighting design developments that have not been conducted.

Suggestions

The development of decorative lighting with the application of visual Pawukon has an opportunity to introduce visual Pawukon to the general public. The potential to raise Lampu Kurung Wuku as a traditional art product for the Solo community, given that decorative lighting that has developed in several cities in Indonesia is a work of old traditions and needs to be preserved. Cities in Java Island such as Gresik, Kebumen, Semarang, Bali, and Solo have traditional decorative lightings, such as lanterns or cage lamps.

\section{References}

[1] Studyanto A, Setyawan S, Widayat R. Visual Application Pawukon On Wall Lamp. In: Saddhono, Kundharu; Ardianto, Deny Tri , Krichkanok Sudasna, Hasnul Jamal B Saidon, KhwanrChinda AT bin A, editor. CONVASH 2019 [Internet]. Surakarta: EAI; 2019. p. 79. Available from: http://dx.doi.org/10.4108/eai.2-11-2019.2294940

[2] Sindhunata G, Hermanu. Pawukon 3000. Yogyakarta: Bentara Budaya Yogyakarta; 2013.

[3] Adisukma W. Hermeneutika pawukon jawa [Internet]. Surakarta; 2018. Available from: http://repository.isi-ska.ac.id/3346/

[4] Meij D Van der. Gods, birds, and trees; Variation in illustrated Javanese pawukon manuscripts. Wacana. 2019;20(1):135.

[5] Widayat R, Studyanto A. Wangun Visual Concept In Pawukon Figures And Interior Design Contexts. Mudra J Seni Budaya [Internet]. 2018;33(3):421. Available from: https://jurnal.isidps.ac.id/index.php/mudra/article/view/546

[6] Tanoyo R. Primbon Pawukon. Solo: Sadu Budi;

[7] Mulyono D. Kalender Pawukon 200 Tahun 1900-2100. 1st ed. Jakarta: Studio Delapan puluh Enterprise; 1993.142 p.

[8] Universitas Sebelas Maret. Tentang UNS [Internet]. Available from: https://uns.ac.id/id/tentanguns/sejarah-uns 